Economics Series

No. 122, November 2011

Who Should Bear the Cost of China's Carbon Emissions Embodied in Goods for Exports?

ZhongXiang Zhang

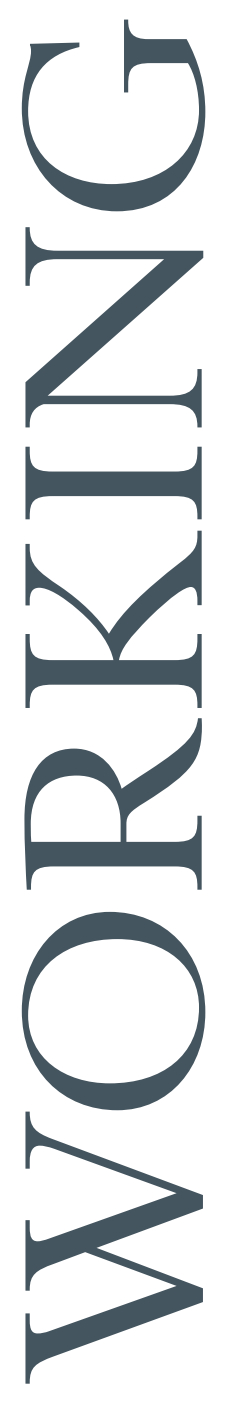

E. E A S T - W ES T C E N T E R 
The East-West Center promotes better relations and understanding among the people and nations of the United States, Asia, and the Pacific through cooperative study, research, and dialogue. Established by the U.S. Congress in 1960, the Center serves as a resource for information and analysis on critical issues of common concern, bringing people together to exchange views, build expertise, and develop policy options.

The Center's 21-acre Honolulu campus, adjacent to the University of Hawai'i at Mānoa, is located midway between Asia and the U.S. mainland and features research, residential, and international conference facilities. The Center's Washington, D.C., office focuses on preparing the United States for an era of growing Asia Pacific prominence.

The Center is an independent, public, nonprofit organization with funding from the U.S. government, and additional support provided by private agencies, individuals, foundations, corporations, and governments in the region.

East-West Center Working Papers are circulated for comment and to inform interested colleagues about work in progress at the Center.

For more information about the Center or to order publications, contact:

Publication Sales Office

East-West Center

1601 East-West Road

Honolulu, Hawai‘i 96848-1601

Telephone: 808.944 .7145

Facsimile: 808.944.7376

Email: EWCBooks@EastWestCenter.org

Website: EastWestCenter.org 
VE $\frac{\text { E A S T - W E S T C E N T E R }}{\text { Collaboration + expertise - leadership }}$

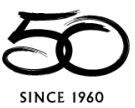

SINCE 1960

\section{Economics Series}

No. 122, November 2011

\section{Who Should Bear the Cost of China's Carbon Emissions Embodied in Goods for Exports?}

\author{
ZhongXiang Zhang
}

ZhongXiang Zhang is a senior fellow at the East-West Center. Currently, he is a co-editor of both Environmental Economics and Policy Studies (the official journal of the Society of Environmental Economics and Policy Studies) and International Journal of Ecological Economics and Statistics, and serves on the editorial boards of nine leading international journals and two Chinese journals. He is among the most cited authors by IPCC Climate Change 2001: Mitigation and IPCC Climate Change 2007: Mitigation of Climate Change, and by Trade and Climate Change: WTO-UNEP Report.
East-West Center Working Papers: Economics Series is an unreviewed and unedited prepublication series reporting on research in progress. The views expressed are those of the author(s) and are not necessarily those of the East-West Center. Working Papers are available for free in PDF format on the Center's website at EastWestCenter.org/ewcworkingpapers. To order print copies (\$3.00 each plus shipping and handling), contact the Center's Publication Sales Office. 


\title{
Who Should Bear the Cost of China's Carbon Emissions Embodied in Goods for Exports?
}

\author{
ZhongXiang Zhang, Ph.D in Economics \\ 张中祥 美国东西方中心研究部资深研究员、经济学博士 \\ Senior Fellow \\ Research Program \\ East-West Center \\ 1601 East-West Road \\ Honolulu, HI 96848-1601 \\ United States \\ Tel: $+1-808-9447265$ \\ Fax: +1-808-944 7298 \\ Email: ZhangZ@EastWestCenter.org
}

\begin{abstract}
China's capital-intensive, export-oriented, spectacular economic growth since launching its open-door policy and economic reforms in late 1978 not only has created jobs and has lifted millions of the Chinese people out of poverty, but also has given rise to unprecedented environmental pollution and $\mathrm{CO}_{2}$ emissions. While estimates of the embedded $\mathrm{CO}_{2}$ emissions in China's trade differ, both single country studies for China and global studies show a hefty chunk of China's $\mathrm{CO}_{2}$ emissions embedded in trade. This portion of $\mathrm{CO}_{2}$ emissions had helped to turn China into the world's largest carbon emitter, and is further widening its gap with the second largest emitter. This raises the issue of who should be responsible for this portion of emissions and bearing the carbon cost of exports. China certainly wants importers to cover some, if not all, of that costs. While China's stance is understandable, this paper has argued from a broad and balanced perspective that if this is pushed too far, it will not help to find solutions to this issue. On the contrary it can be to China's disadvantage for a number of reasons. However, aligning this responsibility with China does not necessarily suggest the sole reliance on domestic actions. In that context, the paper recommends specific actions that need to be taken internationally as well as domestically in order to effectively control the embedded $\mathrm{CO}_{2}$ emissions in China's trade.
\end{abstract}

Keywords: Carbon emissions embodied in trade; Consumption-based accounting; Production-based accounting; Processing trade; Carbon tariffs; Energy policy

JEL classification: F18; P28; Q42; Q43; Q48; Q53; Q54; Q56; Q58 


\section{Introduction}

China had been the world's second largest carbon emitter behind the U.S. for years. Based on the trends in the 1980s and 1990s, the U.S. EIA (2004) estimated that China's $\mathrm{CO}_{2}$ emissions are not expected to catch up with the world's largest carbon emitter by 2030. This seems to have been implanted in people's minds until the International Energy Agency (IEA) indicated in April 2007 that China will overtake the U.S. as the world's largest carbon emitter in 2007 or 2008. The Chinese senior official at the National Coordination Committee on Climate Change immediately rebutted that claim, criticizing the lack of statistical evidence. Yet that IEA claim is an estimate for the future, based on current trends. Although the time span for such an estimate is as short as one year or two years, it is not the historical statistics on carbon emissions. So using a lack of statistical basis to reject that claim is not compelling (Zhang 2007b). This early remark by the IEA had been incorporated into the findings of its flagship report World Energy Outlook 2007, reaffirming that China was already ranked number one as the world's largest carbon emitter in 2007 (IEA 2007). Another study estimates that China's $\mathrm{CO}_{2}$ emissions surpassed those of the U.S. by 8\% in 2006 (MNP 2007).

China's high absolute $\mathrm{CO}_{2}$ emission levels are the combined effects of a large population and unprecedented urbanization, a coal-fueled, energy inefficient and rapidly growing economy, and an unusually large share of energy-intensive industrial production and an unusually small share of the less energy-intensive service sector. Being the workshop of the world also leads to a hefty chunk of China's $\mathrm{CO}_{2}$ emissions embedded (or embodied, which is used inter-exchangeably throughout this paper) in goods that are exported to industrialized countries as well as to other developing countries (e.g., IEA 2007; Davis and Caldeira 2010; Peters and Hertwich 2008; Peters et al. 2011; Shui and Harriss 2006; Weber et al. 2008). Following brief discussion on the magnitude of China's $\mathrm{CO}_{2}$ emissions embodied in trade, this paper will focus on the issue of who should be responsible for this portion of emissions and bearing the carbon cost of exports. This is a very sensitive and complex issue. China certainly wants importers to cover some, if not all, of the costs of that. While China's stance is understandable, this paper has argued from a broad and balanced perspective that if this is pushed too far, it will not help to find solutions to this issue. On the contrary it can be to China's disadvantage for a number of reasons.

However, assigning China's responsibility for its carbon emissions embodied in exports does not necessarily suggest the sole reliance on domestic actions. To effectively control the embedded $\mathrm{CO}_{2}$ emissions in China's trade, actions need to be taken internationally as well as domestically. At the domestic level, the paper suggests that China needs to focus on restructuring and rebalancing its economy through adjusting some policies including pro-trade policies, upgrading its trade structure and energy mix, improving energy efficiency, and strengthening the implementation and enforcement of environmental regulations and standards to prod companies to take increasing corporate social responsibility. At the international level, China and the international community need to strengthen coordination in the internalization of the carbon costs, ensuring that the costs of carbon emissions embodied in traded goods be reflected in the price to the consuming countries as well as those goods for domestic use. This is a feasible means of passing through a carbon cost to consumers without consumption-based accounting of $\mathrm{CO}_{2}$ emissions. Moreover, given that developing countries have explicitly linked progress 
in climate finance commitments from industrialized countries with many other issues in international climate change negotiations, the paper concludes that the delivery of their climate finance pledges will not only help build trust with their developing country counterparts and break current impasses in international climate change negotiations, but also is crucial to enabling China to accelerate its future development along a more sustainable path.

\section{How significantly $\mathrm{CO}_{2}$ emissions embodied in trade and China's contribution?}

Under the accounting rules of the Intergovernmental Panel on Climate Change (IPCC), all greenhouse gas emissions and removals are based on in-country production emissions. Commitments under the United Nations Framework Convention on Climate Change (UNFCCC), the Kyoto Protocol, and its follow-up regimes are set and evaluated based on this territorial-based emissions accounting system.

While Wyckoff and Ropp (1994) raised the trade-related emissions issue by estimating the emissions embodied in manufactured imports of six OECD (Organisation for Economic Co-operation and Development) countries, it is only recently that the issue of consumption-based accounting of $\mathrm{CO}_{2}$ emissions has begun to emerge in analytical literature serving the debate on the future climate change regime. Two examples are the OECD study by Ahmad and Wyckoff (2003) and the OECD Roundtable on Sustainable Development study (Harrison et al. 2003) on embodied $\mathrm{CO}_{2}$ emissions in international trade. The two studies conclude that the current focus on in-country production emissions alone tells only part of the story because a country's global impact in sustainability terms may be distorted by the fact that current measures based on production emissions do not take into account embodied $\mathrm{CO}_{2}$ emissions in international trade. So a country's measured emissions levels may be misleadingly low under the Kyoto accounting framework if it produces very few emissions but imports large quantities of goods whose production gives rise to significant emissions, indicating that a production-based indicator which does not take into account trade flows can give a misleading underestimation of the emissions caused by a country's consumption patterns. At a minimum, these findings point out the importance of a better understanding of consumption trends so that efforts by industrialized countries to address climate change are not overestimated or overstated by focusing just on in-country production emissions and correspondingly, that the global challenge ahead is not underestimated.

In recognition of the importance of trade in regional emissions trends, a number of studies have since attempted to quantify the contribution of embodied $\mathrm{CO}_{2}$ emissions in international trade in more detail and with different geographical coverage. Recent studies of the most broadest country and sector coverage - one by Davis and Caldeira (2010) and another by Peters et al. (2011) - have quantified embodied $\mathrm{CO}_{2}$ emissions in global trade involving 113 countries and 57 economic sectors from 1990 to 2008 . Peters et al. (2011) found that the $\mathrm{CO}_{2}$ emissions from the production of traded goods and services increased from $4.3 \mathrm{Gt} \mathrm{CO}_{2}$ in 1990 to $7.8 \mathrm{Gt} \mathrm{CO}_{2}$ in 2008 . Measured as a percentage of global $\mathrm{CO}_{2}$ emissions, the contribution of embodied $\mathrm{CO}_{2}$ emissions rose to $26 \%$ in 2008 from $20 \%$ in 1990 and $23 \%$ in 2004.

China has often been taken as a case either in a single China country study or as a separate region in a global study, given China as the workshop of the world and its 
export-driven economy, which are expected to lead to a chunk of its emissions embedded in goods that are exported to industrialized countries as well as to other developing countries. Estimates of the embedded $\mathrm{CO}_{2}$ emissions in China's trade differ. They depend on the boundary assumed in the calculation of embedded $\mathrm{CO}_{2}$ emissions, the choice of methodology (top-down input-output analysis versus bottom-up production processes of specific products) and the treatment of technology and emission intensity data across trading partners. Country-specific, detailed energy and carbon intensity data and technology level required is crucial to the accuracy of the calculations. Simply assuming either all imports produced using Chinese domestic technologies or all Chinese exports produced using American domestic technologies (e.g., Shui and Harriss 2006) may overestimate or underestimate China's $\mathrm{CO}_{2}$ emissions embedded in trade because it fails to capture potentially large national differences in technology levels across trading partners. For example, assuming that the imports were produced using Chinese domestic technologies, Peters et al. (2007) estimate $\mathrm{CO}_{2}$ emissions embedded in imports account for 34\% of China's total emissions in 2002. But a later and more accurate estimate based on the technology level in each exporting country puts a value at $6.6 \%$ (Peters and Hertwich 2008).

It should be pointed out that although these studies adopt different methodologies and use different datasets, they tend to draw similar conclusions. That is, given that foreign trade has shown a remarkable growth in China, China is by far the largest net exporter of $\mathrm{CO}_{2}$ emissions. Davis and Caldeira (2010) show that net exports accounted for $22.5 \%$ of production-based CO2 emissions in China in 2004. Peters et al. (2011) find that Chinese emissions accounted for $55 \%$ of the growth in global $\mathrm{CO}_{2}$ emissions from 1990 to 2008 and the production of Chinese exports accounted for $18 \%$ of the growth in global $\mathrm{CO}_{2}$ emissions. Another observation is that, measured as a percentage of total $\mathrm{CO}_{2}$ emissions produced in China, a single country study for China tends to give a higher estimate for the embedded $\mathrm{CO}_{2}$ emissions than those global studies based on more accurate country trade flow and technology details. Pan et al. (2008) estimate China's $\mathrm{CO}_{2}$ emissions embodied in trade at $19 \%$ in 2001 and $30 \%$ in 2006 of its productionbased emissions. By contrast, Figure 1 shows China's $\mathrm{CO}_{2}$ emissions, both productionand consumption-based, and its net emission transfers as a percentage of total productionbased emissions from 1990 to 2008 from a comprehensive global study based on more accurate country trade flow and technology details of 113 countries and 57 economic sectors. Given rapid increases in China's trade since its accesses to the World Trade Organization (WTO) in December 2001 (Figure 2), as would be expected, China's $\mathrm{CO}_{2}$ emissions, both production- and consumption-based, have been increasing rapidly since 2002 (Figures 1-2). Coincidentally, it is since 2002 that China reversed a decline trend in its energy intensity which had gripped over the last two decades in the past century, experiencing faster energy consumption growth than economic growth (see Figure 3). It would be silly to blame this on the U.S., but if the U.S. had not withdrawn from the Kyoto Protocol in 2001, for its own competiveness concerns alone then the U.S. would have kept the pressure on China just like it did immediately after Kyoto and is currently doing, and China's actual greenhouse gas emissions would be lower than their current levels (Zhang 2011b). Moreover, the gap between the production- and consumptionbased $\mathrm{CO}_{2}$ emissions had been widening before the global financial crisis, with net emission transfer increasing from $11 \%$ in 2001 to $21 \%$ in 2007 . While the global 
financial crisis had tempered the rapid growth of China's trade, China's $\mathrm{CO}_{2}$ emissions in trade still accounted for $19 \%$ of its total production-based emissions in 2008.

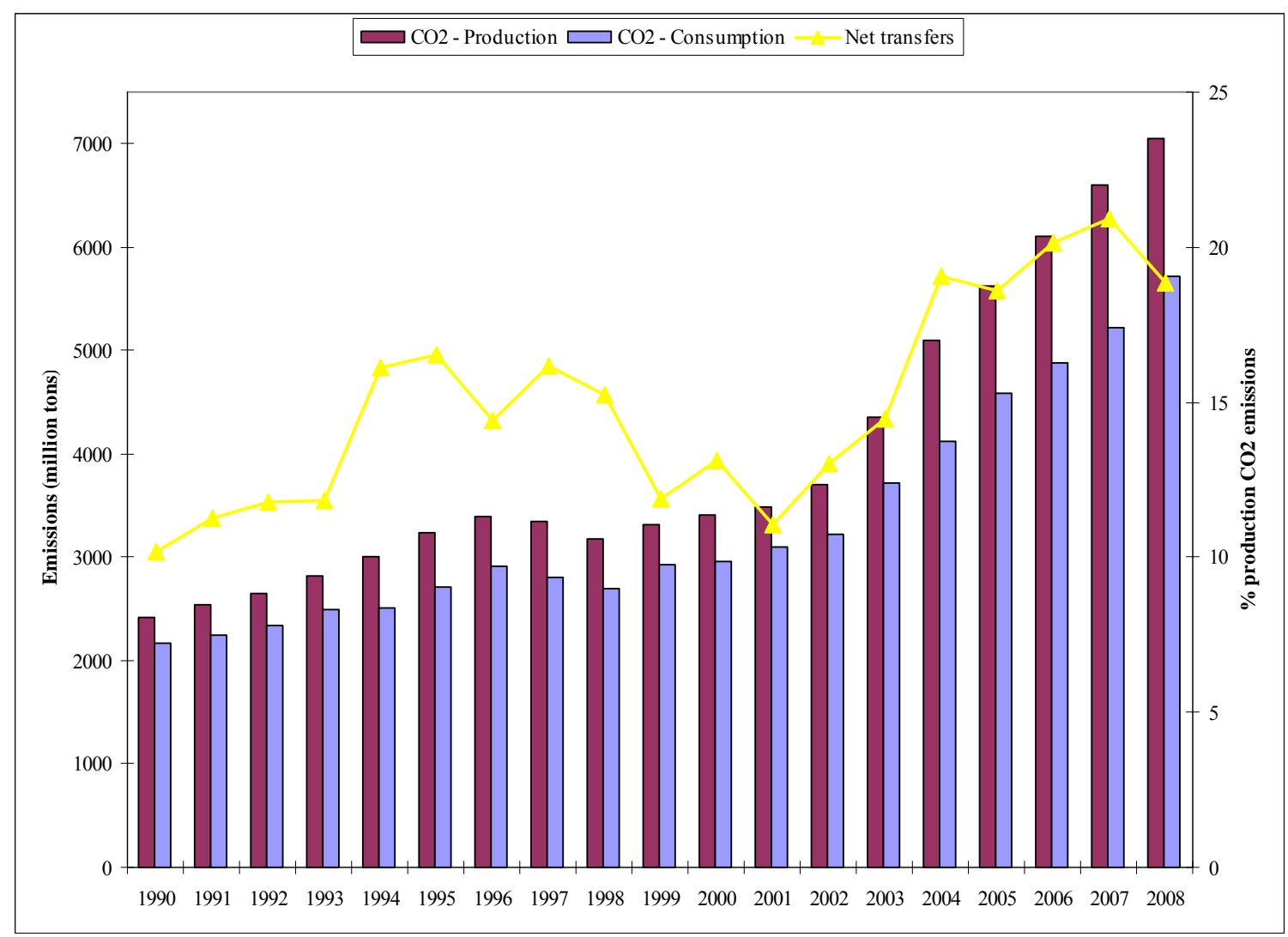

Figure 1 China's production- and consumption-based $\mathrm{CO}_{2}$ emissions (million tons) and net emission transfers as percentages of its production-based $\mathrm{CO}_{2}$ emissions, 1990-2008

Source: Drawn based on Peters et al. (2011). 


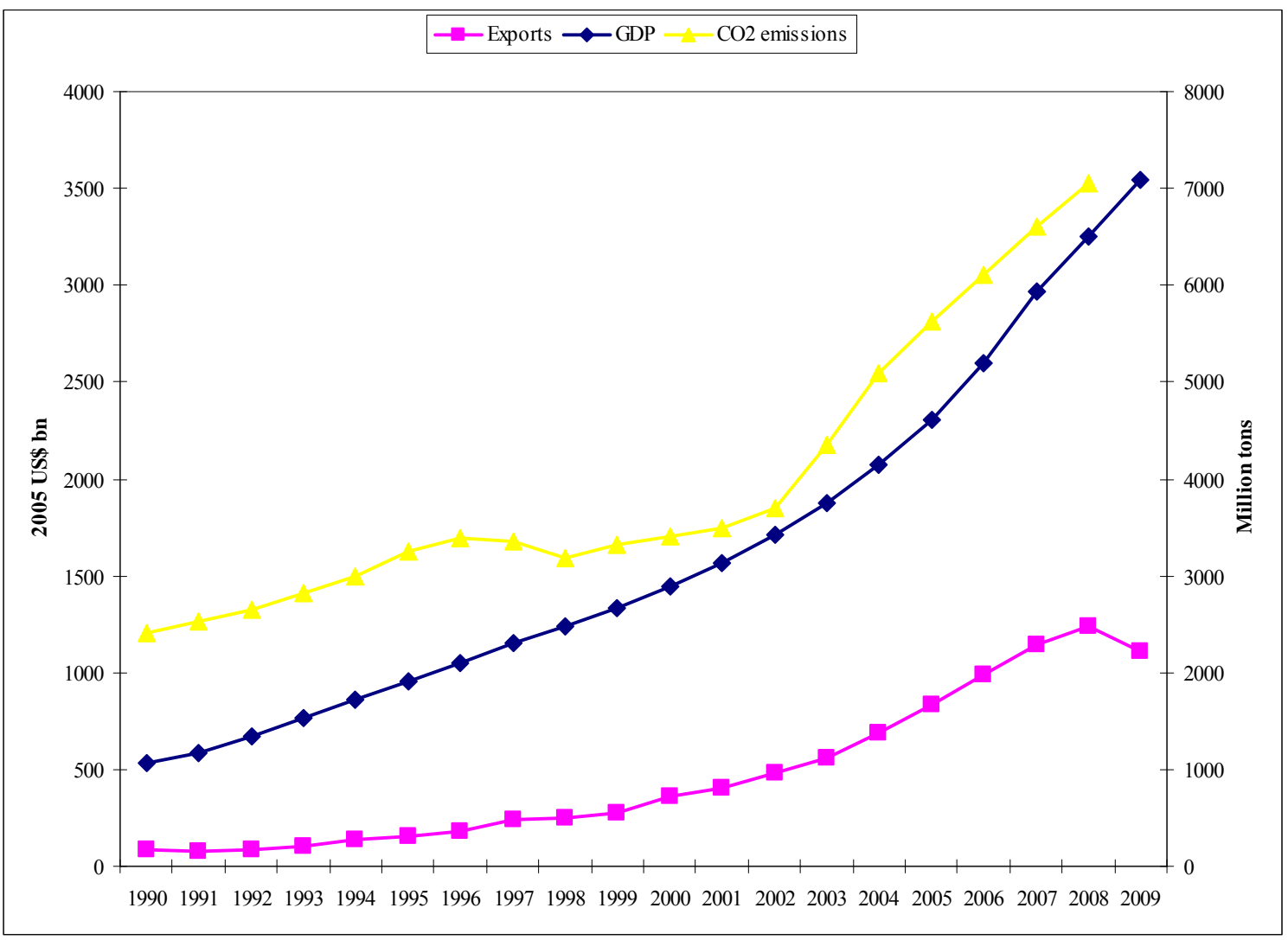

Figure 2 China's GDP, exports and $\mathrm{CO}_{2}$ emissions, 1990-2009

Sources: Drawn based on Peters et al. (2011) and the United Nations Statistic Division (2010). 


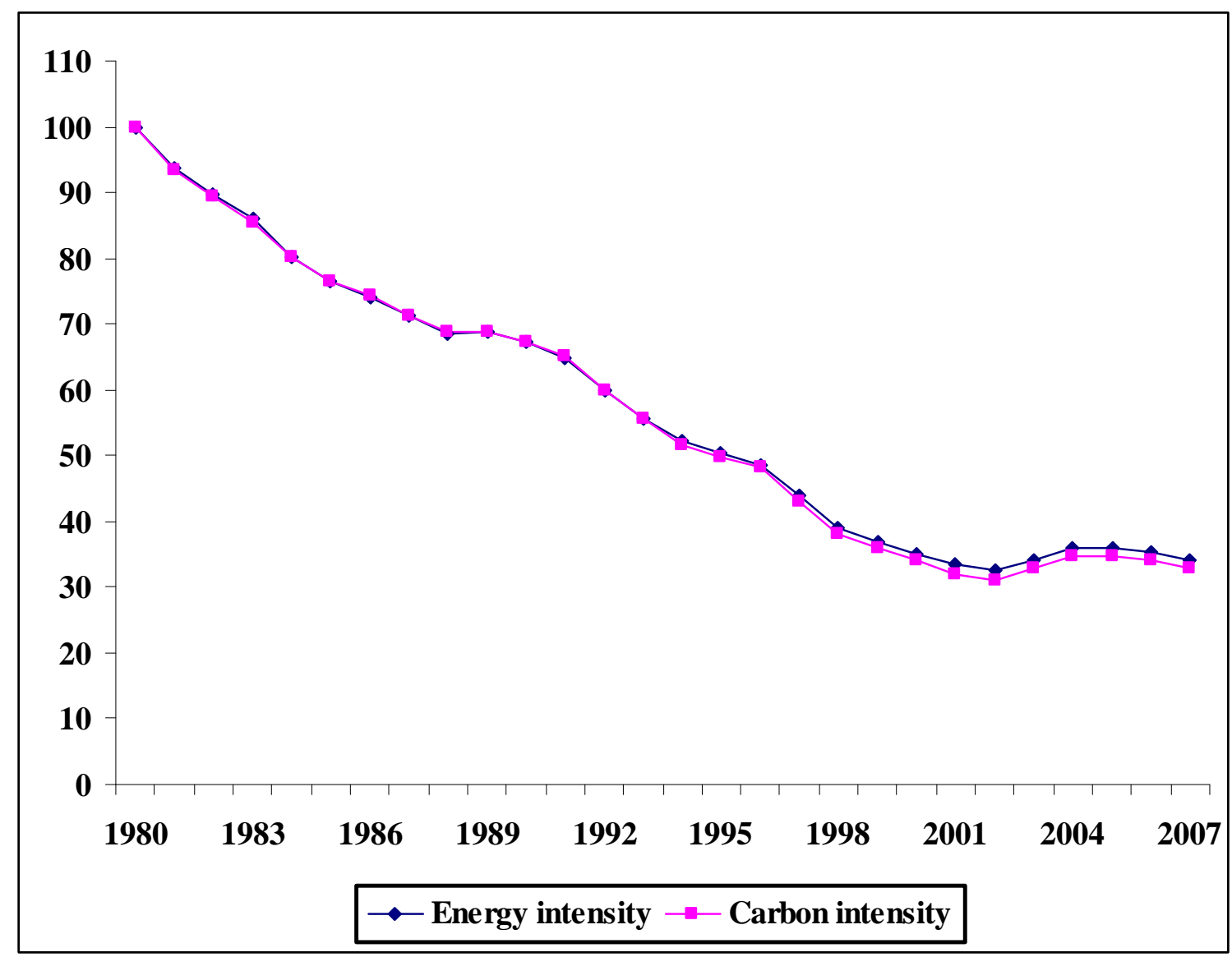

Figure 3 China's energy intensity index and carbon intensity index $(1980=100)$, 1980-2007

Sources: Drawn based on China Statistical Yearbook, various years, and Zhang (1997).

\section{Who should be responsible for China's $\mathrm{CO}_{2}$ emissions embodied in trade?}

While estimates of the embedded $\mathrm{CO}_{2}$ emissions in China's trade differ, both single country studies for China and global studies found a hefty chunk of China's $\mathrm{CO}_{2}$ emissions embedded in trade. This portion of $\mathrm{CO}_{2}$ emissions had helped to turn China into the world's largest carbon emitter, and further widens its gap with the second largest emitter. This raises the issue of who should be responsible for this portion of emissions and bearing the carbon cost of exports (Ball 2009). Should the exporting countries be responsible for consumption needs of importing countries? This is a very sensitive and complex issue. However, this issue of whether the responsibility for externality caused by traded goods lies with producers or consumers is not new. It has perplexed international discussions on traded hardwoods for many years, where the externality may be distributed between the exporting country and the importing country. Another example is related to trade in the "virtual water", which refers to the water used in the production processes of agricultural or industrial product (see the research program on Virtual Water Trade at the United Nations Educational, Scientific and Cultural OrganizationInternational Hydrological Programme (Hoekstra and Hung 2002; Chapagain and 
Hoekstra 2003)). So a water-scarce country can import products that require a lot of water in their production (the so-called import of "virtual water" as opposed to import of real water), thus relieving the pressure on its own water resources. The dispute between China and the EU over the exports of coking coal in the first half of 2004 also had a nexus between producers and consumers. The EU closed many of its own coking plants for environmental reasons, but pressed China to supply coking coal for its steelmakers. The EU even threatened to take China to the WTO if China refused to revoke restrictions on exports by 14 May 2004 and thus allow the EU to import coking coal at previous levels. ${ }^{1}$

China certainly wants importers to cover some, if not complete, of the costs of that (China Daily 2009). This was raised by Ma Kai, the then Chairman of the National Development and Reform Commission, China's top economic planning agency overseeing national economic planning and climate response issues, at a press conference organized by the Information Office of the State Council on 4 June 2007 (NDRC 2007). China's view is on the grounds that when a country's $\mathrm{CO}_{2}$ emissions data for production is higher than that for consumption, the country is in effect emitting $\mathrm{CO}_{2}$ to meet the consumption needs of other countries. China's stance is understandable. Pointing this out at least helps to have a better understanding of China's emissions and their contributions, find solutions to address this issue and to bridge the gap between the concerns of China and developed countries. However, if China follows some analysts to push this too far, on the contrary it can be to China's disadvantage. Let me explain why.

China as the workshop of the world is largely the result of a comparative advantage in the division of trade. Using less energy-efficient technologies to produce goods for domestic use and exports is also largely dictated by its current stage of development. Having said that, it is fair to say that rapidly rising carbon emissions and emissions embedded in exports are also the results of China's own failure to keep the expansion of inefficient and highly polluting industries under control and to implement its own set industrial restructuring and sustainable development policies on the one hand (Zhang 2007a, 2010a,c and 2011c) and its deliberate, pro-trade policies on the other hand. China has not only adopted the common pro-trade policies, such as the depressed exchange rate and export tax rebates, but has long used access to its unique giant customer base as bargaining chips to persuade (or "as leverage to force" as called by some U.S. law makers) foreign companies to open factories within its borders. China not only has been criticized for keeping its currency artificially low, but also has confronted with many disputes with its trading partners. They include and are not limited to the auto

\footnotetext{
${ }^{1}$ Historically, conflicts over trade have almost always been about import barriers. It remains to be seen whether the current WTO rules are strong enough to resolve the growing number of disputes over restrictions on exports. The first test in the WTO is a complaint filed in 2009 by the U.S., the European Union and Mexico, challenging alleged Chinese export restrictions on nine key raw materials such as coke, bauxite, fluorspar and magnesium. A second, and much tougher test, will come if the U.S., the EU, Japan and other affected countries follow up by filing a WTO complaint challenging increasing Chinese restrictions on the export of rare earth elements (Bacchus 2010).
} 
part tariffs (see Box 1), the 70\% local content requirement for wind power projects, ${ }^{2}$ the export quotas on nine metal ores and other raw materials, and the export quotas on rare earths. While China may not admit it, all these policies are partly, if not completely, intended to encourage foreign companies, in particular high-tech companies to move production to China. ${ }^{3}$ With criticisms from and complaints by its trading partners, China eventually abolished its policies on the auto part tariffs and the local content requirement for wind power projects. Responding to a complaint by the United States, the European Union and Mexico, the WTO Dispute Settlement Panel ruled on 5 July 2011 that the quotas imposed by China on exports of nine metal ores and other raw materials vital to steel, chemical, aluminum and other industries violate international trade rules (WTO 2011).

At the core of this raw materials case is whether the WTO will allow export restrictions to be used to protect the environment, an argument China has used to justify limits on exports, including of rare earth ores under GATT (General Agreement on Tariffs and Trade) Article XX. The raw materials panel concluded that since China's WTO agreement did not specifically invoke GATT rules for export duties relating to these products, China can not now base its defense on a GATT provision. The Dispute Settlement Panel went on to say that even if an environmental defense were available in such cases, China did not meet the legal burden of proving such a defense in the raw materials dispute (WTO 2011). To justify that those restrictions would contribute to the conservation of exhaustible natural resources and human health, China needs to demonstrate that it imposed these export restrictions in conjunction with restrictions on domestic production or consumption of the raw materials so as to conserve the raw materials. Put simply, in claiming an environmental defense, China needs to demonstrate while it has limited exports to foreigners, whether it has simultaneously taken steps to limit domestic production or consumption, which is required under the GATT rule for such an environmental defense. China's Ministry of Commence states that China will follow the WTO provisions, applying the same policy to domestic consumption of these materials in China as that to foreign ones. This case does not touch on rare earths specifically, but the facts and legal concepts are very similar between the raw materials case and rare earths. However, no formal case has yet been brought concerning rare earths because the affected countries are closely watching the final resolution of the raw materials case. China has appealed to the WTO Appellate Body. Its final ruling will be a decisive factor for the U.S., the European Union and Japan to determine whether to file a separate WTO complaint on China's rare earths policy.

\footnotetext{
2 This requirement means that wind power projects must have over $70 \%$ of their turbine components locally made, and that the wind turbine generator must be assembled in China. See Zhang (2010c and 2011c) for further discussion.

${ }^{3}$ Until Western governments, business groups and media began pointing out the issues of WTO consistency, Chinese officials had repeatedly stated that the policies were intended to encourage companies to move production to China. They switched to emphasizing environmental protection as the trade issues became salient (Bradsher 2011).
} 


\section{BOX 1 CHINA'S DISPUTE ON AUTOMOBILE PART TARIFFS UNDER WTO}

China lost its first-ever dispute with World Trade Organization on 18 July 2008, when a panel on the WTO compliance of its auto part tariffs found in favor of the complainants Canada, the EU and the U.S. China imposed in April 2005 a 25\% tariff on imported auto parts, if the parts made up $60 \%$ or more of the value of a whole vehicle (Shen et al. 2008; WTO 2009). This tariff rate equals the duty that China applies on imported automobiles but exceeds its $10 \%$ tariff ceiling on imported auto parts. China had contended that the higher tariff was necessary to prevent tax evasion by companies that import whole cars as spare parts and then assemble them together inside China to avoid the higher tariffs applicable to entire automobiles. However, the three complainants in the case maintained that these higher charges unfairly discriminate against the use of foreign auto parts and effectively subsidize domestic production. The complainants argued that the tariff not only discouraged auto manufactures in China from using the imported parts, but also that the higher tariff put pressure on foreign producers of auto parts to relocate manufacturing facilities to China. On 15 September 2008, China notified its decision to appeal to the Appellate Body. On 15 December 2008, the Appellate Body reports were circulated to Members, upholding the Dispute Settlement Panel's findings (WTO 2009). As a response to the WTO decision, China decided since 1 September 2009 to give up this practice that had been implemented for the past four years and to impose a uniform $10 \%$ tariff on all imported auto parts (NDRC et al. 2009). Given the fact that Chinese auto manufactures tend to produce cars with engines smaller than 2.5 liters and an amazing coincidence of timing (the decision to make a large, upward adjustment in consumption tax for gasguzzler cars since 1 September 2008 (see Table 1) was less than a month after China lost its WTO dispute), this move may be seen as a way for China to cut car imports without offending the WTO.

Fundamentally speaking, no one/country forces China to produce a disproportionate amount of goods for exports. On the contrary, the U.S. and other countries, as well as economists such as Paul Krugman (2009), have accused China for creating an imbalance of world trade by the artificial depression of its exchange rate to promote its exports, although they may exaggerate the extent of China's influence (UNCTAD 2011) ${ }^{4}$ and it is still questionable whether China's practice can be adjudicated to be "manipulation" under international law (Staiger and Sykes 2010). If one follows China's argument that these are European and American emissions, then it can be equally

\footnotetext{
${ }^{4}$ UNCTAD (2011) in its policy brief recommends the use of the real effective exchange rate as a practical and effective indicator to differentiate between sustainable and unsustainable trade imbalances. It argues that a real effective exchange rate based on unit labor costs is better suited to grasp changes in competitiveness than one based on consumer price inflation. The latter misses out important elements of the catching-up process of developing countries and may result in significant misinterpretation for some important emerging economies like China.
} 
argued that these must have been European and American jobs. ${ }^{5}$ That puts globalization, jobs and climate change into the same dispute, and here you have the makings of a nasty trade fight (The Economist 2008). Given that job outsourcing in the current economic crisis is extremely sensitive in the U.S. and EU, this does not do any good for China. In particular, the U.S. has already had huge trade deficit with China, and has concerned about further deterioration of its trade balance sheet with China. Pushing the responsibility of the consumers in importing countries is definitely a tough sell to the U.S. It may well be taken out of the context and be used to tackle China for other real matters. ${ }^{6}$ Thus, China needs to treat, with caution, any issue that may potentially worsen or relate to the trade deficit that it has with the U.S. Given that most carbon-intensive industries in the U.S. run a substantial trade deficit (Houser et al. 2008), the U.S. may well argue that imposing carbon tariffs and/or pushing for China to take on carbon emissions caps as early as 2020 aims to reduce $\mathrm{CO}_{2}$ emissions embedded in goods imported from China by levelling the carbon playing field for domestic producers and importers.

\section{Table 1 Consumption tax rates for cars in China}

\begin{tabular}{lccc}
\hline Engine (liters) & $\begin{array}{c}\text { Excise tax since 1 } \\
\text { January 1994 }(\%)\end{array}$ & $\begin{array}{c}\text { Excise tax since 1 } \\
\text { April 2006 }(\%)\end{array}$ & $\begin{array}{c}\text { Excise tax since 1 } \\
\text { September 2008 (\%) }\end{array}$ \\
\hline 1.0 or less & 3 & 3 & 1 \\
$1.0<$ engine $\leq 1.5$ & 5 & 3 & 3 \\
$1.5<$ engine $\leq 2.0$ & 5 & 5 & 5 \\
$2.0<$ engine $\leq 2.5$ & 5 & 9 & 9 \\
$2.5<$ engine $\leq 3.0$ & 5 & 12 & 12 \\
$3.0<$ engine $\leq 4.0$ & 5 & 15 & 25 \\
Greater than 4 & 8 & 20 & 40 \\
\hline
\end{tabular}

Source: Zhang (2010c).

\footnotetext{
${ }^{5}$ This is not just about China versus industrialized countries. There is a bearing on developing countries as well. It could bring China in conflict with other developing countries. Gallagher and Porzecanski (2010) calculate the extent to which Chinese companies are outcompeting their Latin American counterparts. They show that Latin America is under a trade threat from China as well. Their analysis finds that $92 \%$ of Latin America's manufacturing exports were under threat from China by 2009, representing $39 \%$ of Latin America's total exports.

${ }^{6}$ When an issue in question has heavy dose of politics, no matter how small the impact the issue itself has, it can be amplified and taken out of context making it potential implications non-trivial. The Chinese food safety issue in the U.S. is an example. No one would deny that China needs to take food safety concern seriously for the sake of both its own citizens and consumers elsewhere. However, the issue has enlarged beyond that by the politicians and the media due to the trade imbalance between the two countries.
} 
Moreover, China can be partly, if not equally, charged as guilty as the others. While China never admits any wrongdoing and states that it will join international efforts to tackle illegal logging and timber trade, Greenpeace (2006) and Environmental Investigation Agency (2005) have criticized China for the responsibility of illegal logging and deforestation in the Paradise Forests of Asia Pacific, which stretch from Southeast Asia across the islands of Indonesia and on towards Papua New Guinea and the Solomon Islands in the Pacific. Their investigations reveal that such an illegal logging and deforestation is driven by China's imports of a huge amount of timber for making timber products for its own use and exports to satisfy the rising, global demand for inexpensive wood products (Reuters 2007). Existing studies on $\mathrm{CO}_{2}$ emissions embodied in trade only consider energy-related $\mathrm{CO}_{2}$ emissions, and do not factor in the contributions of land use change and forests to $\mathrm{CO}_{2}$ emissions. If the latter factors are brought into equation, then China's act arguably reduces these countries' capacity to use forests as a sink to absorb global carbon and increases the $\mathrm{CO}_{2}$ emissions embodied in its imports.

Consumption-based accounting of $\mathrm{CO}_{2}$ emissions further complicates current debate on the legitimacy of carbon tariffs. The U.S. legislators proposed to use border adjustment measures in the form of emissions allowance requirements (EAR) under the U.S. proposed cap-and-trade regime to level the carbon playing field. In the U.S. House of Representatives, the American Clean Energy and Security Act of 2009 (H.R. 2998) (U.S. House of Representatives 2009), sponsored by Reps. Henry Waxman (D-CA) and Edward Markey (D-MA), was narrowly passed on 26 June 2009. The so-called WaxmanMarkey bill requires importers to acquire and surrender emissions allowances corresponding to the embedded carbon contents in their goods from countries that have not taken climate actions comparable to that of the importing country. This carbon tariff proposal has drawn fierce criticism from China and India. Without specific reference to the U.S. or the Waxman-Markey bill, China's Ministry of Commerce said in a statement posted on its website that proposals to impose carbon tariffs on imported products will violate the rules of the WTO. That would enable developed countries to "resort to trade in the name of protecting the environment". The carbon tariff proposal runs against the principle of common but differentiated responsibilities, the spirit of the Kyoto Protocol. This will neither help strengthen confidence that the international community can cooperate to handle the (economic) crisis, nor help any country's endeavors during the climate change negotiations. Thus, China is strongly opposed to it (MOC of China 2009). A World Bank study by Mattoo et al. (2009) shows that such a carbon tariff would cut China's manufacturing exports by $21 \%$ and India's by $16 \%$. No wonder that China and India warned angrily of trade wars if such border adjustment taxes were imposed (The Economist 2009a). However, if the consumption-based accounting of $\mathrm{CO}_{2}$ emissions, either implicitly or explicitly, is to indicate that the responsibility for the $\mathrm{CO}_{2}$ emissions from the production of traded goods and services lies with the consumers in importing countries, it can then be argued that the final responsibility for regulating those $\mathrm{CO}_{2}$ emissions lies with the governments of importing countries. ${ }^{7}$ Given that most carbon-

\footnotetext{
${ }^{7}$ This is just one of the arguments for carbon tariffs. There are many factors that need to be considered in order to ensure that trade measures would withstand a challenge by trading partners before the WTO. See Zhang (2009, 2010b and 2011c) for detailed discussion on the WTO scrutiny of emissions allowance requirements under a cap-and-
} 
intensive industries in the U.S. run a substantial trade deficit, this proposed EAR clearly aims to level the carbon playing field for domestic producers and importers.

Furthermore, this type of thinking ignores the dynamics of China's future development. For decades, China's blistering growth has depended on exports and investment. The Chinese leaders have recognized that this capital-intensive, exportoriented growth model is no longer sustainable. Accordingly, China's current $12^{\text {th }}$ fiveyear economic plan (2011-2015) focuses on rebalancing an export-driven economy. As a result, the Chinese economy is becoming more oriented towards the domestic market and China is moving to allow its currency to appreciate more rapidly and more broadly against the currencies of all its trading partners. China has also adopted the concept of inclusive growth to seek to ensure equal access to opportunities and balance economic and social development with environmental costs. In the domestic context, inclusive growth means that China's economic and social development should guarantee a higher standards of living for its people, which requires changing its current low wage or practice to keep the costs of labor low in order to boost its exports. With all these changes gradually taking place, China will rely less on trade to drive its economic growth. As would be expected, the share of China's carbon emissions embedded in exports is expected to fall over time.

Finally, attributing emissions to consumers advocates the idea on who consumes is responsible for pollution from consumed goods. If one accepts this consumers pay principle and takes it into broad context, arguably it is rich people who are high emitters and therefore are responsible for emissions in their countries. Following this logic, each country would then have the task of reducing its national consumption according to its number of high emitters - people with an extravagant output of carbon (The Economist 2009b). If the goal were to cap $\mathrm{CO}_{2}$ emissions at 30 billion tons in 2030 and the personal emissions target would be set at around 10.8 tons of $\mathrm{CO}_{2}$ emissions per year, that would mean squeezing the behavior of some 1.1 billion high emitters worldwide. China would have 300 millions of people over this level by 2030, meaning that the country's carbon emissions should rise to no more than 8.5 billion tons in 2030, in comparison with the 11.4 billion tons projected under the business as usual scenario (Chakravarty et al. 2009). Currently, this is just a fresh thinking, and has not been considered the main stream thinking of allocating national emissions targets. However, if a consumption basis is pushed too far, then the idea of basing the number of high emitters to determine allowed national emissions levels may gain its relevance. If this is the case, then the increasing number of high-living, carbon-guzzling rich Chinese people would not be able to hide behind their poor and carbon-thrifty compatriots anymore and, as the aforementioned results suggest, China would be asked to take on emissions caps even earlier and more stringent than China would wish.

trade regime proposed in the Lieberman-Warner bill in the U.S. Senate and in the Waxman-Markey bill in the U.S. House of Representatives, whether an EAR threat would be effective as an inducement for major emerging economies to take climate actions that they would otherwise not, and methodological challenges in implementing EAR. 


\section{Implications of China's $\mathrm{CO}_{2}$ emissions embodied in trade}

China has put a variety of national policies to boost industry and trade. These policies should be responsible for the resulting $\mathrm{CO}_{2}$ emissions. In comparison with other countries at its income level, China has an unusually large share of energy-intensive industrial production and an unusually small share of the less energy-intensive service sector. For example, $49 \%$ of China's gross domestic product (GDP) in 2008 originated from the industry sector and $40 \%$ from the service sector, while the corresponding figures for India were $29 \%$ and $54 \%$, respectively. Moreover, the differing composition of industry affects the levels of energy intensity. China has a larger share of energy-intensive manufacturing in industry than that in India, with manufacturing contributing to $34 \%$ of China's GDP in 2008 relative to the corresponding 16\% for India (World Bank 2010). ${ }^{8}$ In recognition of the negative implications of its industry-oriented economy structure, China sets the target to reduce the share of industry and increase the share of services in its GDP in the $11^{\text {th }}$ five-year economic plan period running from 2006 to 2010. Accordingly, the Chinese government has taken great efforts towards changing the current energy-inefficient and environmentally-unfriendly pattern of industrial growth. With a surge in energy use in heavy industry, the Ministry of Finance of China and the State Administration of Taxation started levying export taxes from November 2006 on a variety of energy- and resource-intensive products to discourage exports of those products that rely heavily on energy and resources, to help save scarce energy and resources. This included a 5\% export tax on oil, coal and coke; a 10\% tax on non-ferrous metals, some minerals and 27 other iron and steel products; and a 15\% tax charged on copper, nickel, aluminum and other metallurgical products. Simultaneously, import tariffs on a range of items, including 26 energy and resource products such as oil, coal and aluminum, were cut from their existing levels of 3-6\% to 0-3\%. From 1 July 2007, the Ministry of Finance of China and the State Administration of Taxation (2007) eliminated or cut export tax rebates for 2831 exported items. This was considered as the boldest move to rein in exports since China joined the WTO in December 2001. Among the affected items, which account for 37\% of all traded products, were 553 'highly energy-consuming, highly-polluting and resourceintensive products', such as cement, fertilizer and non-ferrous metals, whose export tax rebates were completely eliminated. This policy helps to enhance energy efficiency and rationalize energy- and resource-intensive sectors as well as controlling soaring exports and deflating the ballooning trade surplus. It will also help to control China's $\mathrm{CO}_{2}$ emissions in exports.

From the point of view of leveling the carbon cost playing field, such export taxes increase the price at which energy-intensive products made in China, such as steel and aluminum, are traded in world markets. For the EU and U.S. producers, such export taxes imposed by their major trading partner on these products take out at least part, if not all, of the competitive pressure that is at the heart of the carbon leakage debates. Being converted into the implicit carbon costs, the estimated levels of $\mathrm{CO}_{2}$ price embedded in the Chinese export taxes on steel and aluminium are very much in the same range as the

${ }^{8}$ Given that China's GDP was 3.5-4.0 times that of India in 2008 (World Bank 2010), this suggests that, in volume terms, energy-intensive manufacturing in China values 7-8 times that of India. Clearly, carbon tariffs have a greater impact on China than on India (Zhang 2010b). 
average price of the EU allowances over the same period. Zhang $(2009,2010 \mathrm{~b}$ and 2011c) have argued that there is a clear need within a climate regime to define comparable efforts towards climate mitigation and adaptation to discipline the use of unilateral trade measures at the international level. As exemplified by export tariffs that China applied voluntarily during 2006-2008, defining the comparability of climate efforts can be to China's advantage (Zhang 2010b).

These policies brought positive outcomes, but are not enough. In the end, China failed to reach its own set goals of economic restructuring in 2010. To control the growth of its increasing demand for energy and oil imports as well as China's $\mathrm{CO}_{2}$ emissions in exports, China needs to strengthen its efforts to keep the expansion of inefficient and highly polluting industries under control and to implement its own set industrial restructuring and sustainable development policies.

China also needs to adjust its current trade structure. Processing trade involves importing goods and re-exporting the imported goods after being processed. Since the processing trade policy was implemented in late 1970s, the processing trade in China has been developing in a sustained and rapid manner; the total volume of exports and imports in the form of processing trade increased from US\$ 2.5 billion in 1981 to US\$ 831.9 billion in 2006, up by nearly 333 times. Its proportion in total foreign trade increased from $5.7 \%$ to $48.6 \%$ during this period. While its share has dropped in recent years, processing trade has still accounted for more than $41 \%$ of China's total trade. Based on panel data covering China's 51 trading partners from 1993-2008, Xin (2011) shows that processing trade accounts for $100 \%$ of China's overall trade surplus and can explain most of its bilateral trade balances. However, no matter how useful it is in promoting the development and job creation, China needs to upgrade the processing trade. This is considered essential not only to deepening China's opening-up and maintaining its international competitive edge, but also to improving the environment and limiting $\mathrm{CO}_{2}$ emissions.

The Chinese government clearly recognizes the importance. In addition to supportive economic policies and market-based environmental instruments, governments are exploring industrial policies to promote industrial upgrading and energy conservation. Ministry of Commerce of China and the State Environmental Protection Agency (2007) in October 2007 were in an unusual collaboration to jointly issue the antipollution circular. Targeted at the booming export industry, this new regulation would suspend the rights of those enterprises that do not meet their environmental obligations to engage foreign trade in the period of more than one year and less than three years. A significant portion of China's air pollution can be traced directly to the production of goods that are exported. In the Pearl River Delta, a major manufacturing region in Southern China, as indicated in Figure 4, Streets et al. (2006) found that $37 \%$ of the total $\mathrm{SO}_{2}$ emissions in the region, $28 \%$ of nitrogen oxides $\left(\mathrm{NO}_{\mathrm{x}}\right), 24 \%$ of particulate matter $(\mathrm{PM})$, and $8 \%$ of volatile organic compounds (VOCs) are caused by export-related activities. In the city of Shenzhen alone, the regional leader in industrial development and trade, $75 \%$ of VOCs, $71 \%$ of $\mathrm{PM}, 91 \%$ of $\mathrm{NO}_{\mathrm{x}}$, and $89 \%$ of $\mathrm{SO}_{2}$ emissions from the industrial sector were released in the manufacturing of exported goods. Effectively implemented, this policy should help polluting enterprises that export their products to pay attention to the environmental effects of their products and produce more environmentally friendly products. 

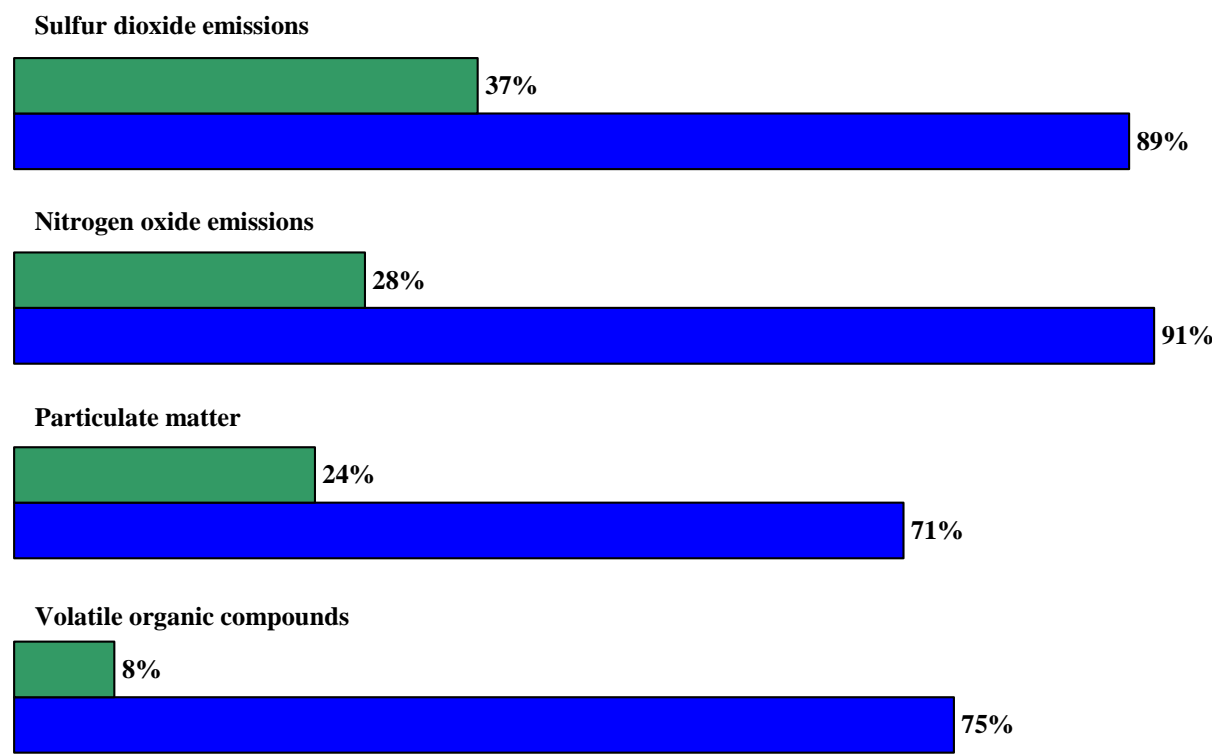

Figure 4 Percentage of air pollutants tied to export manufacturing in the Pearl River Delta and Shenzhen, China

Source: Streets et al. (2006).

Cutting China's $\mathrm{CO}_{2}$ emissions in exports creates a new impetus for upgrading its energy mix. China has relied on coal for about $70 \%$ of its total energy consumption over the past decades to fuel its rapidly growing economy. Therefore, the amount of $\mathrm{CO}_{2}$ emissions in China and from the production of Chinese exports is attributed to this coaldominated energy mix in China. If the country could significantly cut the share of coal in its energy mix, then the amount of $\mathrm{CO}_{2}$ emissions in China and from the production of Chinese exports would be reduced dramatically, even if it would remain the largest carbon emitter in the world. A country's choice of fuels and technologies depends to a large extent on its resource endowments and their relative prices. The fact that countries like China and India use more coal is not because they prefer it, but because of their abundant supplies of coal and its relatively lower price compared with its more environmentally friendly substitutes. The trade-related emissions issue has created a new impetus for encouraging the use of renewables and improving energy efficiency. Increasing this share not only enhances energy security, but also is environmentally friendly and conducive to good health. China had made great efforts in this area and has already committed itself to quantified targets on energy conservation and the use of clean energy. It needs to extend its level of ambition, making further credible quantified domestic commitments in these areas for the second commitment period and beyond. Taking many factors into consideration, Zhang $(2010 \mathrm{c}, 2011 \mathrm{~b}, \mathrm{c})$ argue that China needs to take on absolute emissions caps around 2030. However, it is hard to imagine how 
China could apply the brakes so sharply as to switch from rapid emissions growth to immediate emissions cuts, without passing through several intermediate phases. To that end, Zhang (2010c, 2011b,c) envision that China needs the following three transitional periods of increasing climate obligations before taking on absolute emissions caps that will lead to the global convergence of per capita emissions by 2050: first, further credible energy conservation commitments starting in 2013 and aimed at cutting China's carbon intensity by $46-50 \%$ by 2020 (Zhang 2011a); second, voluntary "no lose" emission targets starting in 2018; and third, binding carbon intensity targets as its international commitment starting in 2023. Overall, this proposal is a balanced reflection of respecting China's rights to grow and recognizing China's growing responsibility for increasing greenhouse gas emissions as China is approaching to be the world's largest economy.

Cutting China's $\mathrm{CO}_{2}$ emissions in production of goods for domestic consumption and exports also requires increasing corporate social responsibility. While governments determine the rules under which businesses act, set environmental goals and commit to international environmental agreements, they count on enterprises' full cooperation. After all, the enterprises themselves are entities that make investment, use natural resources, produce products and emit pollution. Foreign-invested enterprises have played a vital role in boosting China's trade. They have produced more than half of its exports, and have dominated in its exports of electronics and information and communication technology, accounting for more than $80 \%$ of China's exports of these goods (Xin 2011). They accordingly contribute to an increase in $\mathrm{CO}_{2}$ emissions produced in production of their products for exports. Given that foreign-invested enterprises, in particular multilateral corporations have financial resources and advanced technologies and management, they are well positioned to set good examples for local Chinese enterprises, including the compliance with environmental regulations standards. Their policies and strategies have huge implications for others, in particular their suppliers. For example, until 2008 WalMart had adopted the "always low prices" as its slogan. While it benefits consumers by keeping prices low, this practice comes at the cost of the environment. Keeping prices low will put pressure on its suppliers, in particular those small suppliers, and squeeze their profit margins. While multilateral corporations state that they are committed to the high standards of social responsibility, keeping artificially low prices throughout their supply base leaves their suppliers little or no room to internalize their externality costs. Some have even no choice but to disregard the environment to win orders from multilateral corporations. Recently, Chinese environmental groups have accused Apple suppliers for pollution in China (Hook and Hille 2011). This is partly attributed to Apple low purchasing price in its supply chain. Moreover, some transnational corporations operate with double environmental standards, adopting low standards in their subsidiaries in developing countries where there is the absence or lack of industry-specific national standards or the implementation of these standards are weak, although they are capable of improving the environmental performance of their subsidiaries. It has been widely reported that over one hundred of multilateral corporations in China were blacklisted for being noncompliance with China's environmental regulations (Sina Net 2008). This is not in China alone. It is also in other developing countries, including those more advanced developing countries. Focusing on the rapidly developing electronics assembly industry in the three border cities, Juárez, Mexicali and Tijuana in North Mexico, Schatan and Castilleja (2007) found that $89 \%$ of the plants surveyed are foreign owned and many of 
their parent companies had introduced significant environmental measures in their countries of origin. However, only slightly over half of the plants analyzed had implemented an active environmental policy in Mexico.

\section{Conclusions}

China's capital-intensive, export-oriented, spectacular economic growth since launching its open-door policy and economic reforms in late 1978 not only has created jobs and has lifted hundreds of millions of the Chinese people out of poverty, but also has given rise to unprecedented environmental pollution and $\mathrm{CO}_{2}$ emissions. Estimates of the embedded $\mathrm{CO}_{2}$ emissions in China's trade differ, depending on the boundary assumed in the calculation of embedded $\mathrm{CO}_{2}$ emissions, the choice of methodology and the treatment of technology and emission intensity data across trading partners. Measured as a percentage of total $\mathrm{CO}_{2}$ emissions produced in China, global studies based on more accurate country trade flow and technology details tend to give a lower estimate of the embedded $\mathrm{CO}_{2}$ emissions than those single country study for China, which may fail to capture potentially large national differences in technology levels between China and its trading partners. However, both types of studies show that a hefty chunk of China's $\mathrm{CO}_{2}$ emissions are embedded in trade. This portion of $\mathrm{CO}_{2}$ emissions had helped to turn China into the world's largest $\mathrm{CO}_{2}$ emitter, and is further widening its gap with the second largest emitter.

Who should be responsible for this portion of emissions and bearing the carbon cost of exports is a very sensitive and complex issue. China certainly wants importers to cover some, if not all, of the costs of that. China's stance is understandable. Pointing this out at least helps to have a better understanding of China's emissions and their contributions and bridge the gap between the concerns of China and developed countries. However, if this is pushed too far, this paper has argued from a broad and balanced perspective that on the contrary it can be to China's disadvantage for several reasons.

First, China as the workshop of the world is largely the result of a comparative advantage in the division of trade. Using less energy-efficient technologies to produce goods for domestic use and exports is also largely dictated by its current stage of development. It is fair to say that rapidly rising carbon emissions and emissions embedded in exports are also the results of China's deliberate, pro-trade policies. China has not only adopted the common pro-trade policies, such as the depressed exchange rate and export tax rebates, but has long used access to its unique giant customer base and accesses to its certain raw materials and rare earth elements as leverage to induce foreign companies to open factories in China or relocate their production to China. China not only has been criticized for keeping its currency artificially low, but also has confronted with many disputes with its trading partners, including the auto part tariffs, the local content requirement for wind power projects, the export quotas on nine metal ores and other raw materials, and the export quotas on rare earths. If one follows China's argument that these are European and American emissions from China's own deliberate pro-trade policies, then it can be equally argued that these must have been European and American jobs. Given that job outsourcing in the current economic crisis is extremely sensitive in the U.S. and EU, this does not do any good for China. Combined with the U.S. concerns about existing huge trade deficit and further deterioration of its trade balance sheet with 
China, pushing the responsibility of the consumers in importing countries is definitely a tough sell to the U.S. Moreover, this is not just about China versus industrialized countries. It has a bearing on developing countries as well.

Second, China can be partly, if not equally, charged as guilty as the others. While China never admits any wrongdoing and states that it will join international efforts to tackle illegal logging and timber trade, China has long been criticized for the responsibility of illegal logging and deforestation in Southeast Asia, in particular Myanmar and Indonesia. Existing studies on $\mathrm{CO}_{2}$ emissions embodied in trade only consider energy-related $\mathrm{CO}_{2}$ emissions, and do not factor in the contributions of land use change and forests to $\mathrm{CO}_{2}$ emissions. If the latter factors are brought into equation, then China's act arguably reduces these countries' capacity to use forests as a sink to absorb global carbon and increases the $\mathrm{CO}_{2}$ emissions embodied in its imports.

Third, consumption-based accounting of $\mathrm{CO}_{2}$ emissions further complicates current debate on the legitimacy of carbon tariffs. The U.S. proposed carbon tariffs have drawn fierce criticism from China and India. However, if the consumption-based accounting of $\mathrm{CO}_{2}$ emissions, either implicitly or explicitly, is to indicate that the responsibility for the $\mathrm{CO}_{2}$ emissions from the production of traded goods and services lies with the consumers in importing countries, it can then be argued that the final responsibility for regulating those $\mathrm{CO}_{2}$ emissions lies with the governments of importing countries.

Fourth, this type of thinking ignores the dynamics of China's future development. The savvy Chinese leaders have recognized that China's capital-intensive, exportoriented growth model over the past decades is no longer sustainable. Accordingly, China's current $12^{\text {th }}$ five-year economic plan focuses on rebalancing an export-driven economy and inclusive growth, aiming for reliance less on trade and more on domestic consumption to drive its economic growth. As would be expected, the share of China's carbon emissions embedded in exports is expected to fall over time.

Fifth, attributing emissions to consumers advocates the idea on who consumes is responsible for pollution from consumed goods. If one takes this consumers pay principle into broad context, arguably it is rich people who are high emitters and therefore are responsible for emissions in their countries. Provided that the idea of basing the number of high emitters to determine allowed national emissions levels would gain its relevance, then the increasing number of high-living, carbon-guzzling rich Chinese people would not be able to hide behind their poor and carbon-thrifty compatriots anymore and China would accordingly be asked to take on emissions caps even earlier and more stringent than China would wish.

While the aforementioned reasons argue that China is responsible for its carbon emissions embodied in exports, it does not necessarily suggest the sole reliance on domestic actions, no actions at the international level. In fact, to effectively control the embedded $\mathrm{CO}_{2}$ emissions in China's trade, actions need to be taken internationally as well as domestically. At the national level, China needs to focus on rebalancing its investment-driven, export-oriented economy, boosting the service sector and domestic consumption and allowing its currency to appreciate more rapidly and more broadly to reflect its real value. In this regard, it is crucial for China to take significant efforts to keep the expansion of inefficient and highly polluting industries under control and to implement its own set industrial restructuring and sustainable development policies. 
China also needs to adjust its current trade structure. Processing trade has played a significant role in promoting development and job creation in China. However, no matter how useful it is, China needs to upgrade the processing trade. This is considered essential not only to deepening China's opening-up and maintaining its international competitive edge, but also to improving the environment and limiting $\mathrm{CO}_{2}$ emissions in production of goods for exports as well as for domestic consumption.

Cutting China's $\mathrm{CO}_{2}$ emissions in exports creates a new impetus for upgrading its energy mix and improving energy efficiency. China had made great efforts in this area and has already committed itself to quantified targets on energy conservation, the use of clean energy and carbon intensity. It needs to extend its level of ambition, aiming for a $46-50 \%$ cut in its carbon intensity by 2020 and taking on absolute emissions caps around 2030 that will lead to the global convergence of per capita $\mathrm{CO}_{2}$ emissions by 2050 . With rising domestic energy demand and increasing difficulty further cutting energy and carbon intensities, putting a price on carbon is considered a crucial step for China's endeavor of harnessing the market force to reduce its energy consumption and carbon emissions and genuinely transiting into a low-carbon economy. It will make consumers, be they in China or abroad, to bear the carbon costs. China is experimenting low-carbon provinces and low-carbon cities in five provinces and eight cities. Aligned with such experiment, a carbon tax or a domestic carbon trading scheme, if established, will serve as a cost-effective supplement to costly administrative means on which China has mainly relied to meet its energy-saving goal in 2010. However, in terms of timing, given that China has not levied environmental taxes yet, it is better to introduce environmental taxes first, followed by carbon taxes, not least because such a distinction will enable to disentangle China's additional efforts towards carbon abatement from those broad energy-saving and pollution-cutting ones. In case of a domestic carbon trading scheme, the key issue is its scope and coverage. Given the fact that the costs of abating carbon emissions differ significantly among emissions sources across provinces and sectors, having broad coverage of emissions sources from all industries nationwide creates a means of obtaining low-cost abatement options, thus minimizing the total cost of complying with the national energy-saving and emissions goals. This is an ideal option. In practice, however, carbon trading in China would have to start from selected sectors or regions, although the limited scope and coverage will reduce its cost-effectiveness, because China needs a reasonable length of time to develop and operate a national carbon market. Moreover, to facilitate future integration of these fragmented sectoral or regional schemes into a national emissions trading scheme, the central government should establish from the outset the common standards for any sectoral or regional schemes to be established and implement them strictly.

As experienced in China and elsewhere, even if multilateral corporations, which have financial resources and advanced technologies and management and thus are well positioned to set good examples for local enterprises, operate with double environmental standards, adopting low standards in their subsidiaries in developing countries. Quite a few even do not comply with China's environmental regulations. Clearly, cutting China's $\mathrm{CO}_{2}$ emissions in production of goods for exports as well as for domestic consumption requires strengthening the implementation and enforcement of environmental regulations and standards. This will prod companies to take increasing corporate social responsibility. 
Just like any country that will concern about the potential competitiveness loss of unilateral imposition of carbon prices, China is no exception. At the international level, cutting China's $\mathrm{CO}_{2}$ emissions in exports therefore creates a new impetus for strengthening international coordination on climate change and establishing a global carbon price framework. It is the absence of a global carbon price that has failed to internalize the carbon costs. Given that the internalization of carbon costs will send a clear signal to both producers and consumers, therefore China and the international community need to strengthen coordination in the internalization of the carbon costs, ensuring that the costs of carbon emissions embodied in traded goods be reflected in the price to the consuming countries as well as those goods for domestic use. This is a feasible means of passing through a carbon cost to consumers without consumptionbased accounting of $\mathrm{CO}_{2}$ emissions, which is more data-intensive and complex than production-based accounting of $\mathrm{CO}_{2}$ emissions. In this course, China needs to increase its domestic carbon prices and support more stringent global greenhouse gas emissions reductions to bring about higher, more consistent carbon prices internationally. Moreover, China is still a developing country, no matter how rapidly it is growing. Industrialized countries should significantly scale up their technology transfer and deployment, financing and capacity building to encourage and enable China to undertake more nationally appropriate mitigation actions than would otherwise have been the case. Industrialized countries have promised new and additional climate finance at the Copenhagen climate change conference. While their climate finance pledges are well below expectations and demands from developing countries, industrialized countries have to date failed to keep their climate finance pledges (Ballesteros et al. 2011). Given that developing countries have explicitly linked progress in climate finance commitments from industrialized countries with many other issues in international climate change negotiations, the failure to deliver their pledges will not help build trust with their developing country counterparts and break current impasses in international climate change negotiations. While China has determined to deal with its own unprecedented environmental pollution and rising greenhouse gas emissions from burning fossil fuels and energy security as a result of steeply rising oil imports, international support is still crucial to enabling China to accelerate its future development along a more sustainable path. Given the coal-dominated energy mix in China, this also means that larger amounts of greenhouse gas emissions in production of goods both for domestic consumption and exports will be avoided than would otherwise have been the case. This helps to mitigate global climate change. Clearly, this is the win-win outcome both for China and global climate change.

\section{Acknowledgments}

I initially talked about the issues related to consumption-based $\mathrm{CO}_{2}$ emissions at the U.S. National Intelligence Council Project's Conference on Climate Change and its Implications through 2020, University of Maryland at College Park, 28 June 2004. The views in this paper in part or whole were also presented at the International Conference on Economic Policy Simulation and Technological Innovation, A Chinese Academy of Social Sciences Forum, Beijing, 5-6 November 2011 and expressed in a series of the seminars in National Climate Center of China Meteorological Administration, the 
Chinese Academy of Sciences, the Chinese Academy of Social Sciences, Energy Research Institute of the National Development and Reform Commission, Peking University and Tsinghua University, Beijing, China. That said, they are those of the author. The author bears sole responsibility for any errors and omissions that may remain.

\section{References}

Ahmad N, Wyckoff A (2003) Carbon dioxide emissions embodied in international trade of goods. OECD DSTI/DOC(2003)15, Organisation for Economic Co-operation and Development, November.

Bacchus J (2010) Hoarding resources threatens free trade: a case against China at the WTO is a sign of an emerging new arena for conflict. Wall Street Journal, 19 May.

Ball P (2009) Who should bear the carbon cost of exports?. Nature, 6 March, available at: http://www.nature.com/news/2009/090306/full/news.2009.133.html.

Ballesteros A, Polycarp C, Stasio K, Chessin K, Easton C (2011) Summary of developed country 'fast-start' climate finance pledges. World Resources Institute, Washington, DC, 20 May.

Bradsher K (2011) Chasing rare earths. New York Times, 25 August.

Chakravarty S, Chikkatur A, Conink H. de, Pacala S, Socolow R, Tavoni M (2009). Sharing global $\mathrm{CO}_{2}$ emission reductions among one billion high emitters. Proceedings of National Academy of Sciences 106 (29): 11884-11888.

Chapagain AK, Hoekstra AY (2003) Virtual water flows between nations in relation to trade in livestock and livestock products. Value of Water Research Report Series No. 13, UNESCO-IHE, Delft, The Netherlands.

China Daily (2009) China wants importers to cover emission costs. 17 March, available at: http://www.chinadaily.com.cn/bizchina/2009-03/17/content 7586768.htm.

Davis SJ, Caldeira K (2010) Consumption-based accounting of $\mathrm{CO}_{2}$ emissions. Proceedings of National Academy of Sciences 107 (12): 5687-5692.

Environmental Investigation Agency (2005) Illegal logging in Papua and China's massive timber theft. London, available at: http://www.eiainternational.org/files/reports93-1.pdf.

Gallagher KG, Porzecanski R (2010) The dragon in the room: China and the future of Latin American industrialization. Stanford University Press, California.

Greenpeace (2006) Sharing the blame: global consumption and China's role in ancient forest destruction. March, available at: http://www.greenpeace.org/eastasia/Global/eastasia/publications/reports/forests/2 006/sharing-the-blame.pdf.

Harrison A, Vitalis V, Upton S (2003) Sustaining whose development? analysing the international effect of national policies. OECD Roundtable on Sustainable Development, Organisation for Economic Co-operation and Development, November.

Hoekstra AY, Hung PQ (2002) Virtual water trade: a quantification of virtual water flows between nations in relation to international crop trade. Value of Water Research Series No. 11, UNESCO-IHE, Delft, The Netherlands. 
Hook L, Hille K (2011) Apple attacked over pollution in China. Financial Times, 31 August.

Houser T, Bradley R, Childs B, Werksman J, Heilmayr R (2008) Leveling the carbon playing field: international competition and U.S. climate policy design. Peterson Institute for International Economics and World Resources Institute, Washington, DC.

IEA (2007) World energy outlook 2007. International Energy Agency (IEA), Paris.

Krugman P (2009) Chinese new year. New York Times, 31 December, available at: http://www.nytimes.com/2010/01/01/opinion/01 krugman.html?th\&emc $=$ th.

Mattoo A, Subramanian A, van der Mensbrugghe D, He J (2009) Reconciling climate change and trade policy. World Bank Working Paper No. 5123, Washington, DC, November.

Ministry of Commerce of China (MOC of China) (2009) A statement on 'carbon tariffs'. Beijing, 3 July, available at: http://www.mofcom.gov.cn/aarticle/ae/ag/200907/20090706375686.html.

Ministry of Finance of China and the State Administration of Taxation (2007) A circular on lowering export tax rebates for some products. 18 June, Beijing, available at: http://finance.sina.com.cn/focus/2007tzckts/index.shtml.

Ministry of Commerce of China and the State Environmental Protection Agency (2007) A circular on strengthening the environmental supervision of export-engaged enterprises. 8 October, Beijing, available at: http:/www.gov.cn/zwgk/200710/12/content 775030.htm.

National Development and Reform Commission (NDRC) (2007) Commissioner Ma Kai responded to climate issues at a press conference organized by the Information Office of the State Council. 4 June, available at: http://www.ndrc.gov.cn/xwfb/t20070604 139560.htm.

National Development and Reform Commission (NDRC), Ministry of Finance, Ministry of Commerce, and the General Administration of Customs (2009) Imports of automobile parts levied at the uniform rate of 10 percent since 1 September. 30 August, Beijing, available at: http://news.sina.com.cn/c/2009-0830/133016209710s.shtml.

Netherlands Environmental Assessment Agency (MNP) (2007) China now no. 1 in $\mathrm{CO}_{2}$ emissions; USA in second position. 19 June.

Pan J, Phillips J, Chen Y (2008) China's balance of emissions embodied in trade: approaches to measurement and allocating international responsibility. Oxford Review of Economic Policy 24 (2): 354-376.

Peters GP, Hertwich EG (2008) $\mathrm{CO}_{2}$ embodied in international trade with implications for global climate policy. Environmental Science and Technology 42: 1401-1407.

Peters GP, Minx JC, Weber CL, Edenhofer O (2011) Growth in emission transfers via international trade from 1990 to 2008. Proceedings of the National Academy of Sciences 108 (2): 8903-8908.

Peters GP, Weber CL, Guan D, Hubacek K (2007) China's growing $\mathrm{CO}_{2}$ emissions: a race between increasing consumption and efficiency gains. Environmental Science and Technology 41: 5939-5944. 
Shen J, Hou L, Lei Z (2008). WTO rules for the first time China's violation of its trade provisions. 14 February, available at: http://news.sina.com.cn/c/2008-0214/165514939341.shtml.

Sina Net (2008) Special topic on over one hundred of multilateral corporations blacklisted for violating the environmental regulations in China. Available at: http://finance.sina.com.cn/focus/kgqyhb/index.shtml.

Reuters (2007) China's demand for hardwood drives illegal logging, says Greenpeace. 17 April, available at: http://news.mongabay.com/2007/0417-reuters.html.

Schatan C, Castilleja L (2007) The Maquiladora electronics industry on Mexico's northern border and the environment. International Environmental Agreements: Politics, Law and Economics 7 (2): 109-135.

Shui B, Harriss RC (2006) The role of $\mathrm{CO}_{2}$ embodiment in US-China trade. Energy Policy 34: 4063-4068.

Staiger RW, Sykes AO (2010) 'Currency manipulation' and world trade. World Trade Review 9 (4): 583-627.

Streets DG, Yu C, Bergin MH, Wang X, Carmichael GR (2006) Modeling study of air pollution due to the manufacture of export goods in China's Pearl River Delta. Environmental Science and Technology 40 (7): 2099-2107.

The Economist (2008) Chinese torture. 7 June, p. 66.

The Economist (2009a) Green with envy: the tension between free trade and capping emissions. 21 November, p. 80.

The Economist (2009b) Climate change talks - wanted: fresh air. 11 July, pp. 60-62.

United Nations Conference on Trade and Development (UNCTAD) (2011) Global imbalances: the choice of the exchange rate-indicator is key. UNCTAD Policy Briefs No.19, UNCTAD/PRESS/PB/2011/1, available at: http://www.unctad.org/en/docs/presspb20111 en.pdf.

United Nations Statistic Division (2010). National accounts main aggregates database. Available at: http://unstats.un.org/unsd/snaama/Introduction.asp.

U.S. EIA (2004) International energy outlook 2004. U.S. Energy Information Administration (EIA), Washington, DC.

U.S. House of Representatives (2009) H.R. 2998. 23 June, available at: http://frwebgate.access.gpo.gov/cgibin/getdoc.cgi?dbname=111 cong_bills\&docid=f:h2998ih.txt.pdf.

Weber CL, Peters, GP, Guan D, Hubacek K (2008) The contribution of Chinese exports to climate change. Energy Policy 36: 3572-3577.

World Bank (2010) World development indicators 2010. Washington, DC.

World Trade Organization (WTO) (2009) China - measures affecting imports of automobile parts. DS340, available at: http://www.wto.org/english/tratop E/dispu e/cases e/ds340 e.htm.

World Trade Organization (WTO) (2011) China - measures related to the exportation of various raw materials. DS394, 5 July, available at: http://www.wto.org/english/tratop_e/dispu_e/cases_e/ds394_e.htm.

Wyckoff AW, Ropp JM (1994) The embodiment of carbon in imports of manufactured products: implications for international agreements on greenhouse gas emissions. Energy Policy 22 (3): 187-194. 
Xin Y (2011) Processing trade, exchange rates, and the People's Republic of China's bilateral trade balances. Asian Development Bank Institute Working Paper 270, Tokyo.

Zhang ZX (1997) The economics of energy policy in China: implications for global climate change. New Horizons in Environmental Economics Series, Edward Elgar, Cheltenham, UK and Northampton, USA.

Zhang ZX (2007a) China's reds embrace green. Far Eastern Economic Review 170 (5): 33-37.

Zhang ZX (2007b) Why has China not embraced a global cap-and-trade regime?. Climate Policy 7 (2): 166-170.

Zhang ZX (2009) Multilateral trade measures in a post-2012 climate change regime?: what can be taken from the Montreal Protocol and the WTO?. Energy Policy 37: $5105-5112$.

Zhang ZX (2010a) Is it fair to treat China a Christmas tree to hang everybody's complaints? putting its own energy-saving into perspective. Energy Economics 32: S47-S56.

Zhang ZX (2010b) The U.S. proposed carbon tariffs, WTO scrutiny and China's responses. International Economics and Economic Policy 7 (2-3): 203-225.

Zhang ZX (2010c) China in the transition to a low-carbon economy. Energy Policy 38: 6638-6653.

Zhang ZX (2011a) Assessing China's carbon intensity pledge for 2020: stringency and credibility issues and their implications. Environmental Economics and Policy Studies 13 (3): 219-235.

Zhang ZX (2011b) In what format and under what timeframe would China take on climate commitments? a roadmap to 2050. International Environmental Agreements: Politics, Law and Economics 11 (3): 245-259.

Zhang ZX (2011c) Energy and environmental policy in China: towards a low-carbon economy. New Horizons in Environmental Economics Series, Edward Elgar, Cheltenham, UK and Northampton, USA. 